\title{
Effect of Time of Sowing on the Yield and Yield Attributes of Barley Under Rainfed Condition
}

\author{
M. A. Razzaque and S. Rafiquzzaman \\ Regional Agricultural Research Station, BARI, Rahmatpur Barisal \\ Pulse Research Centre, BARI, Madharipur, Bangladesh
}

\section{Introduction}

Barley (Hordium vulgare L.) is one of the minor cereal crops grown in Bangladesh during the dry winter season. It grows successfully in a wider range of climate than any other cereals. In Bangladesh only 10000 hectares of land are under barley cultivation where the production is only 6000 metric tons with the average yield of $600 \mathrm{~kg} / \mathrm{ha} .^{1}$

Barley is superior to wheat in some minerals and fiber contents. Barley contains water soluble fibre (betaglucons) and oil compound (tocotrinol) which are found to be effective in lowering cholesterol level of blood. ${ }^{2}$ The crop is sown with minimum care and management under residual moisture. Proper land preparation, application of fertilizers, irrigation, optimum time of sowing, seed rate etc. are not usually practiced in raining this crop. Production trend of barley is declining due to lack of high yielding and superior quality varieties as well as management practices like appropriate sowing time. Knapp and Knapp $^{3}$ reported that increase in the number of spike is the major reason for increased yield with proper sowing time. Early planted crops had more tillers and heads $/ \mathrm{m}^{2}$, heavier grains yield than late planted crop. ${ }^{4}$

Early sowing of winter wheat is likely to expose the crop not only to higher temperature but also a critical day length for flowering. ${ }^{5}$ On the other hand late sowing of wheat and barley might expose the crop to higher temperature after and during heading resulting in reduced number of ears per square meter and number grains / ear. ${ }^{6}$ Higher temperature during vegetative stage results inpoor tillering, growth and development. ${ }^{7}$ Singh et al. found that grain yield of barley decreased at delayed sowing. ${ }^{8}$ The present investigation was therefore undertaken to find out the optimum sowing time to achieve higher yield of barley at farmers field in rainfed condition of southern region of Bangladesh.

\section{Materials and Methods}

The experiment was conducted at farmers field under rainfed condition during the rabi seasons of 1999-2000 and 2000-2001 at the Multi Location Testing site (MLT) Kalapara, 
Patuakhali. The treatment consisted of four dates of sowing (20 November, 30 November 10 December, 20 December) and five genotypes/variety such (BSH-32, BSHL-2, BSH2, BARI Barley-2 and BARI Barley-4). The experiment was laid out in a split plot design with 3 replications where time of planting was assignment in the main plot and genotypes in the sub plot. The unit plot size was $5 \mathrm{~m} \times 3 \mathrm{~m}$ and the crop was sown at spacing of $25 \mathrm{~cm}$ in a solid line. The land was fertilized@ of 80-26-50 kg NPK/ha in the form of urea, triple super phosphate and muriate of potash respectively. All agronomic practices were done according to the crop requirements. A sample area of $3 \mathrm{~m} \times 2 \mathrm{~m}$ was selected randomly from each plot for collections of yield data. The yield parameters like plant height, number of spikes $/ \mathrm{m}^{2}$ number of grains/spike, weight of 1000 grain were measured from 20 randomly selected panicles. The crop was harvested at the ground level when it attained full maturity. The crop under different sowing dates were harvested at different dates depending on maturity. The results were analyzed under computerized statistical program IRRISTAT and means were compared by using LSD.

\section{Result and Discussion}

\section{Plant height}

Plant height was significantly influenced by variety (Table I). The tallest plant $(92.66 \mathrm{~cm})$

Table I. Main effect of sowing and genotype time on the yield and yield contributing characters (pooled) of barley at Kalapara, Patuakhali during 1999-2000 and 2000-2001

\begin{tabular}{c|c|c|c|c|c|c|c}
\hline $\begin{array}{c}\text { Sowing } \\
\text { date }\end{array}$ & $\begin{array}{c}\text { Plant } \\
\text { height }(\mathrm{cm})\end{array}$ & $\begin{array}{c}\text { No of } \\
\text { spikes/m² }\end{array}$ & $\begin{array}{c}\text { Spike } \\
\text { length }(\mathrm{cm})\end{array}$ & $\begin{array}{c}\text { No of } \\
\text { grains/ spike }\end{array}$ & $\begin{array}{c}1000 \text { grain } \\
\text { wt.(g) }\end{array}$ & $\begin{array}{c}\text { Grain } \\
\text { yield kg/ha }\end{array}$ & $\begin{array}{c}\text { Straw yield } \\
\mathrm{kg} / \mathrm{ha}\end{array}$ \\
\hline 20 Nov. & $85.86 \mathrm{a}$ & $204.8 \mathrm{~b}$ & 6.33 & $35.37 \mathrm{a}$ & 25.16 & $1775 \mathrm{a}$ & $2623 \mathrm{a}$ \\
30 Nov. & $85.4 \mathrm{a}$ & $209.93 \mathrm{a}$ & 6.65 & $34.98 \mathrm{bc}$ & 26.04 & $1778 \mathrm{a}$ & $2631 \mathrm{a}$ \\
10 Dec. & $80.53 \mathrm{~b}$ & $202.93 \mathrm{~b}$ & 6.33 & $33.83 \mathrm{~b}$ & 25.83 & $1632 \mathrm{~b}$ & $2412 \mathrm{~b}$ \\
20 Dec. & $74.67 \mathrm{c}$ & $191.53 \mathrm{c}$ & 6.08 & $31.53 \mathrm{c}$ & 23.57 & $1357 \mathrm{c}$ & $2127 \mathrm{c}$ \\
\hline CV (\%) & 2.2 & 0.6 & 4.6 & 1.8 & 5.5 & 1.9 & 1.5 \\
L.S.D (.05) & 3.51 & 2.24 & $\mathrm{~ns}$ & 1.19 & $\mathrm{~ns}$ & 60.88 & 75.05 \\
Genotypes & & & & & & & \\
\hline BSH-32 & 74.92 & 201.25 & 5.73 & 39.13 & 20.87 & 1605 & 2345 \\
BSHL-2 & 81.66 & 188.92 & 5.64 & 30.47 & 23.87 & 1340 & 2031 \\
BSH-2 & 76.66 & 217.33 & 6.39 & 40.62 & 23.69 & 2038 & 3048 \\
BB-2 & 92.66 & 211.92 & 6.80 & 29.63 & 34.25 & 2111 & 3136 \\
BB-4 & 82.17 & 192.08 & 6.67 & 29.76 & 19.52 & 1083 & 1681 \\
\hline CV(\%) & 1.8 & 1.2 & 5.8 & 2.5 & 1.4 & 2.7 & 3.0 \\
LSD(.05) & 2.787 & 4.74 & 0.686 & 1.5 & 0.602 & 82.84 & 137.37 \\
\hline
\end{tabular}


was recorded by BARI Barley-2 and the shortest from the genotype BSH-32 $(74.92 \mathrm{~cm})$. The plant height was significantly influenced by different date of sowing and the tallest plant $(85.86 \mathrm{~cm})$ was obtained from 20 November sowing which was statistically different from other sowing dates. The shortest plant $(74.67 \mathrm{~cm})$ was obtained from 20 December sowing. The results agreed with the finding of Farid and co-workers who reported that the possible causes of decreased plant height in later sowing might be due to decrease in temperature as well as day length which shorten the vegetative growth period. ${ }^{9}$

\section{Number of spike/m²}

Spikes $/ \mathrm{m}^{2}$ was significantly affected by variety and sowing time (Table I). The highest spies $/ \mathrm{m}^{2}$ (217.33) was recorded by genotypes BSH-2 and the lowest from the genotype BSHL-2 (188.92). Identically superior number of spikes $/ \mathrm{m}^{2}$ was found when crop was sown on 30 November (209.3) and 20 November (204.8) and lowest in 20 December (191.53). Sowing in 20 December exposed the crop to higher temperature and longer day length during tillering and grain filling period, which might have reduced the tiller number. Roy and Nafgizer reported the same result. ${ }^{10}$ Hossain and Alam (1986) ${ }^{11}$ also obtained that late planting suffered mostly due to drastic reduction in ear number. The interaction between variety and sowing time had significant effect on production of spikes $/ \mathrm{m}^{2}$ (Table II).

\section{Length of spike}

No significant difference was observed among the sowing time for spike length but variety had significant impact BARI barley-2 produced higher spike length $(6.80 \mathrm{~cm})$ than that of BSH-32 $(5.73 \mathrm{~cm})$. The 30 November sowing produced the length of spike $(6.65 \mathrm{~cm})$ followed by that in 20 November and 10 December $(6.33 \mathrm{~cm})$ The differential behaviour or length of spike due to different sowing date might be explained by the fact that sowing during higher temperature, the plant could not get congenial environment for growth and development affecting development of spike. Similar observation was also reported by Begum et al. ${ }^{12}$

\section{Number of grains/spike}

Number of grains/spike was significantly influenced by the interaction of variety and sowing time (Table II). The result showed that superior numbers of grains/spike was recorded with BSH-2 sown on 20 November (42.6) and 30 November (41.43). This result is in well agreement with the findings of Kamal et al. ${ }^{13}$ and Singh and Dixit. ${ }^{14}$ Joarder et al. ${ }^{15}$ also stated that number of grains/spike decreased with delay in sowing upto December in wheat. The later number was identical to that of the 10 December of the same genotype. The least number of grams/spike (25.26) was observed from the BARI barley-2. The other sowing produced moderate numbers grains/spike. 
Table II. Interaction of sowing date and genotypes on the yield and yield attributes of Barley (Pooled)

\begin{tabular}{c|l|c|c|c|c|c|c|c}
\hline $\begin{array}{c}\text { Sowing } \\
\text { date }\end{array}$ & Variety & $\begin{array}{c}\text { Plant } \\
\text { height cm }\end{array}$ & $\begin{array}{c}\text { No of } \\
\text { spikes/m }\end{array}$ & $\begin{array}{c}\text { Spike } \\
\text { length }(\mathrm{cm})\end{array}$ & $\begin{array}{c}\text { No of } \\
\text { grains/ spike }\end{array}$ & $\begin{array}{c}1000 \text { grain } \\
\text { wt.(g) }\end{array}$ & $\begin{array}{c}\text { Grain yield } \\
\text { kg/ha }\end{array}$ & $\begin{array}{c}\text { Straw yield } \\
\text { kg/ha }\end{array}$ \\
\hline 20 Nov. & BSH-32 & 74.23 & 211.33 & 5.7 & 38.43 & 21.60 & 1708 & 2550 \\
& BSHL-2 & 84.00 & 198.66 & 5.5 & 31.97 & 24.20 & 1497 & 2230 \\
& BSH-2 & 82.33 & 207.33 & 6.1 & 42.6 & 24.06 & 2087 & 3043 \\
& BB-2 & 93.00 & 214.00 & 6.3 & 32.06 & 35.33 & 2365 & 3497 \\
& BB-4 & 95.66 & 192.66 & 6.4 & 31.76 & 20.60 & 1220 & 1795 \\
\hline 30 Nov. & BSH-32 & 80.33 & 206.66 & 6.1 & 40.9 & 20.84 & 1727 & 2576 \\
& BSHL-2 & 86.66 & 189.33 & 6.1 & 30.56 & 24.13 & 1370 & 2060 \\
& BSH-2 & 77.66 & 232.33 & 6.8 & 41.43 & 23.63 & 2223 & 3187 \\
& BB-2 & 98.00 & 220.00 & 7.2 & 31.73 & 35.10 & 2393 & 3390 \\
& BB-4 & 84.33 & 201.33 & 7.0 & 30.27 & 19.87 & 1175 & 1943 \\
\hline 10 Dec. & BSH-32 & 74.66 & 199.66 & 5.6 & 39.4 & 20.97 & 1618 & 2379 \\
& BSHL-2 & 82.66 & 187.66 & 5.8 & 30.3 & 23.83 & 1316 & 1942 \\
& BSH-2 & 75.00 & 223.00 & 6.5 & 40.33 & 23.57 & 2086 & 3099 \\
& BB-2 & 92.66 & 214.33 & 7.0 & 29.47 & 33.77 & 2093 & 3094 \\
& BB-4 & 77.66 & 190.00 & 6.8 & 29.67 & 19.10 & 1047 & 1549 \\
\hline 20 Dec. & BSH-32 & 70.33 & 187.33 & 5.5 & 37.8 & 20.10 & 1368 & 1873 \\
& BSHL-2 & 73.33 & 180.00 & 5.5 & 29.06 & 23.30 & 1176 & 1894 \\
& BSH-2 & 71.67 & 206.66 & 6.2 & 38.13 & 23.10 & 1755 & 2867 \\
& BB-2 & 87.00 & 198.33 & 6.7 & 25.26 & 32.83 & 1593 & 2565 \\
& BB-4 & 71.00 & 184.33 & 6.5 & 27.37 & 18.50 & 891 & 1438 \\
\hline CV(\%) & & 4.8 & 1.2 & 5.4 & 3.9 & 1.1 & 4.2 & 3.4 \\
& & 5.79 & 10.96 & 0.61 & 2.068 & 0.354 & 122.51 & 198.1 \\
\hline
\end{tabular}

\section{0 grain weight}

The interaction of variety and sowing time significantly influenced weight as was observed in BARI barly-2 (35.33g) from 20 November sowing. This was significantly followed by that obtained from BARI barley2 sown on 30 November (35.1g). The least 1000 grain weight (18.5g) was obtained from the BARI barley-2 when sown on 20 December. BARI barley-2 produced intermediate 1000 grain weight in other sowing times. The late sown crop had smaller grain size and was statistically lower than the crop sown earlier. A subsequent decrease in 1000 grain weight in wheat with delayed sowing was reported by Joarder et al. ${ }^{15}$ Sofied et al. ${ }^{16}$ 
reported that higher grain weight was associated with longer grain filling period.

\section{Grain yield}

Grain yield was significantly influenced by the interaction of variety and sowing time (Table II). The result showed that the highest grain yield (2393 kg/ha) was obtained in BARI barley -2 from the 30 November sowing which was statistically identical to 20 November sowing (2365kg/ha) and 30 November sowing genotype BSH-2 (2223 $\mathrm{kg} / \mathrm{ha}$ ) and the later was followed by 10 December. The lowest grain yield (891kg/ha) was obtained from the BARI barley -4 when sown on 20 December. The yield was reduced by late sowing. Sing et al. found that grain yield of barley decreased at delayed sowing from 10-25 December and 10 January. ${ }^{8}$

\section{Straw yield}

Straw yield was also significantly influenced by the interaction of variety and sowing time (Table II). BARI barley produced significantly higher straw yield (3497 kg/ha) from 20 November sowing which was identical to sowing date on 30 November of the same variety and the lowest yield was obtained from BARI barley-4 when sown on 20 December (1438 kg/ha). The crop sown on 30 November produced taller and higher number of spike/ $\mathrm{m}^{2}$ resulting in higher straw yield. Shorter plant and lower number of spikes $/ \mathrm{m}^{2}$ from 20 December sowing mainly attributed to lower straw yield. Vegetative stage of the crop reduced with delayed sowing, continuous low temperature during vegetative stage and temperature at maturity adversely affected the plant height and also the spike formation which ultimately reduced straw yield. ${ }^{17}$

\section{Conclusion}

From the above investigation it can be concluded that variety BARI barley-2 may be the first choice and genotype BSH-2 next choice. So that the optimum sowing time of barley should range from 20 November to 10 December for cultivation at southern region of Bangladesh in rainfed condition.

\section{References}

1. 4. FAO. Food and Agriculture Organization. Year book Vol. No. 50. Food and Agriculture Organization of the United Nations. Rome Italy. (1996) 75.

2. D. Hales. Eat smart, feed good and look great. Readers Digest. New York. Vol. No. 8 ( 1992) 63.

3. W. R. Knapp and J. S. Knapp. Response of winter wheat to date of planting and fertilization. Agron. J. 70(6) (1978) 1048-1053.

4. R. A. Fischer and R. Maurer. Drought resistance in spring wheat cultivars. Aust. J. Agric Res. 29 (1978) 897-912.

5. J. T. Musick and D. A. Dusek. Planting date and water deficit on development and irri- 
gated winter wheat. Agron. J. 72(1) (1980) 45-52.

6. A. S. Randhawa, R. S. Jolly and S. S. Dhillon. Response of wheat and barley to nitrogen and different dates of sowing. Crop Improvement 4(1) (1977) 49-64.

7. S. I. Choudhury and I. F. wardlaw. The effect of temperature on kernel development in cereals. Aust. J. Agric. Res. 29 (1978) 205-223.

8. J. Singh, A. S. Malik and J. Singh. Response of late sown wheat barley and lentil to irrigation levels. Haryana. J Agron. 5(1) (1989) 52-56.

9. S. M. Farid, A. Hossain and A. B. M. Salahuddin. Sowing dates effect on the yield of three cultivars of barley. Bangladesh $J$. Agric Sci. 20(1) (1993) 41-45

10. S. K. Roy and E. D. Nafgier. Effect of sowing date on the yield and yield attribute of three variety of barley. Bangladesh Agron. J. 2(1) (1987) 64-67.

11. M. A. Hossain and N. Alam. Effect of sowing time and seed rate on the yield of wheat (var. Kanchan) under irrigated condition in Bangladesh. In Abst. Paper Bangladesh Soc. Agron. Ann. Conf. Conf. (1986) 8.
12. S. Begum, M. G. Moula., M. A. Rahman and and D. Nessa. Effect of sowing time and seed rate on the yield of barley. Bangladesh J. Agril. Sci. 26(2) (1999) 81-85

13. M. M. Kamal, M. Begum, A. A. Miah and M. R. Khan. Effect of sowing and seed rate on the yield and yield attributes of barley. Bangladesh J. Agril. Res. 23(4) (1998) 625-629.

14. S. B. Singh and H. D.Dixit. Effect of sowing dates on wheat varieties. Indian J. Agron. 30(4) (1995) 512-513.

15. O. I. Joarder, R. Islam, S. Rahman and A. M. Eunus. Effect of seeding date on yield of other agronomic trials of some wheat varieties grown on irrigated lands in Bangladesh. Indian J. Agric. Sci. 51(7) (1981) 489463.

16. I. L. Sofied, T. Evans. M. G. Cook and I. F. Wardlaw. Factor influencing the rate and duration of grain filling in wheat. Aust. J. Physiol. 4 (1977) 785-797.

17. S. K. Agrawal and N. R. Arora. Effect of sowing dates and seed rates on growth and yield of barley varieties. Indian J. Agron. 25(1) (1980) 65-70 